\title{
Skin symptoms as diagnostic clue for autoinflammatory diseases ${ }^{*}$
}

\author{
Alvaro Moreira ${ }^{1,2}$ \\ Juliano Peruzzo ${ }^{5}$ \\ Kilian Eyerich ${ }^{6}$
}

\author{
Barbara Torres ${ }^{3,4}$ \\ Alberto Mota ${ }^{3}$ \\ Johannes Ring ${ }^{2,6}$
}

DOI: http://dx.doi.org/10.1590/abd1806-4841.20175208

\begin{abstract}
Autoinflammatory disorders are immune-mediated diseases with increased production of inflammatory cytokines and absence of detectable autoantibodies. They course with recurrent episodes of systemic inflammation and fever is the most common symptom. Cutaneous manifestations are prevalent and important to diagnosis and early treatment of the syndromes. The purpose of this review is to emphasize to dermatologists the skin symptoms present in these syndromes in order to provide their early diagnosis.

Keywords: Acquired hyperostosis syndrome; Behçet syndrome; Cryopyrin-associated periodic syndromes; Familial mediterranean fever; Mevalonate kinase deficiency; Still's disease, adult-onset; Schnitzler syndrome; Sweet syndrome; Hereditary autoinflammatory diseases; Tumor necrosis factor receptor-associated peptides and proteins
\end{abstract}

\section{INTRODUCTION}

Autoinflammatory disorders are a group of diseases characterized by recurrent episodes of systemic inflammation, with an increased production of inflammatory cytokines that can occur without detectable autoantibodies or auto-reactive T cells. ${ }^{1-5}$ Cutaneous manifestations can be the dominant symptoms in some of the patients and can even be the initial manifestation of the disease. ${ }^{5} \mathrm{Ac}-$ cording to their characteristics, the main cutaneous manifestations of autoinflammatory diseases are grouped into: urticarial exanthema, dermo-hypodermitis, neutrophilic dermatosis, granulomatous dermatitis and bipolar aphthosis.

The identification of genetic polymorphisms and their association with proteins of the inflammasome complex and other regulatory proteins were decisive for a better understating of autoinflammatory diseases. Their spectrum covers monogenic, polygenic and multifactorial diseases. ${ }^{3,6}$ Within the monogenic diseases, we will describe Familial Mediterranean Fever (FMF), Mevalonate Kinase Deficiency (MKD), Majeed Syndrome, PAPA Syndrome (acronym for pyogenic arthritis, pyoderma gangrenosum and acne), TNF Receptor Associated Periodic Syndrome (TRAPS), Cryopyrin-associated Periodic Syndromes (CAPS), Familial Cold Autoinflammatory Syndrome type 2 (FCAS 2), Familial Blau Syndrome and De- ficiency of the Interleukin-1-receptor Antagonist (DIRA). Among polygenic and multifactorial diseases, we will focus on SAPHO Syndrome (acronym for synovitis, acne, pustulosis, hyperostosis, and osteitis), Chronic Recurrent Multifocal Osteomyelitis (CRMO), Systemic Juvenile Idiopathic Arthritis (SJIA), Adult-onset Still's Disease (AOSD), Schnitzler Syndrome, Behçet's Disease, Crohn's Disease and Periodic Fever Aphthous Pharyngitis and cervical Adenopathy (PFAPA).

It is still a matter of discussion whether some of these diseases, such as Behçet's disease, SAPHO, CRMO, AOSD and Schnitzler Syndrome, are genuine autoinflammatory diseases. Innate immune-mediated diseases, which are associated with significant tissue destruction without evident adaptive immune responses, are designated as autoinflammatory (mostly due to distinct immunopathologic features). ${ }^{6}$ This is highly relevant, because innate immune-mediated disorders may respond to cytokine antagonism whereas autoimmune-mediated diseases respond better to anti- $\mathrm{T}$ and $B$ cell therapies.

The purpose of this review is to systematically characterize autoinflammatory disorders and to cluster the cutaneous manifestations of these diseases. This may lead to earlier diagnosis and better

\section{Received on 30.09.2015}

Approved by the Advisory Board and accepted for publication on 12.11.2015

* Study conducted at the Department of Dermatology and Allergy, Technical University of Munich, Munich, Germany

Financial Support: None.

Conflict of Interest: None.

Department of Dermatology, Friedrich-Alexander-University Erlangen-Nürnberg, Erlangen, Germany.

Christine Kühne-Center for Allergy Research and Education, Davos, Switzerland.

Department of Dermatology and Venereology, Faculty of Medicine of the University of Porto, Porto, Portugal.

Unidade de Saúde Familiar Vale de Sorraia, Coruche, Portugal.

Faculdade de Medicina - Universidade Federal do Rio Grande do Sul (UFRGS), Porto Alegre (RS), Brazil.

Department of Dermatology and Allergy, Technical University of Munich, Munich, Germany. 
prevention of severe complications. This review aims to highlight the role of the dermatologist in the early diagnosis of auto-inflammatory diseases.

\section{URTICARIAL EXANTHEMA}

\section{Cryopyrin-associated periodic syndromes (CAPS)}

These autoinflammatory syndromes are rare and comprise three phenotypes with increasing severity: Familial Cold-induced Auto-inflammatory Syndrome (FCAS), Muckle-Wells Syndrome and Neonatal Multisystem Inflammatory Disease (NOMID). ${ }^{7-9}$ They are caused by gain of function mutations in NLRP3, the gene encoding cryopyrin or NALP3 (a protein of the inflammasome), leading to activation of caspase 1 , with the subsequent increase of IL-1ß and IL-18 secretion. ${ }^{7,10-15}$ In about $40 \%$ of patients with cryopyrinopathy there are no known mutations. ${ }^{7}$

The cryopyrinopathies are characterized by cutaneous, articular, neurological and ophthalmic events. ${ }^{9,16}$ Cutaneous manifestations are the key symptom and are often the first manifestation of the disease. They usually appear after birth, in the form of an atypical, migratory rash or less frequently as a maculopapular urticaria-like rash. ${ }^{25,9,11,14}$ Histologic examination confirms the diagnosis at an early stage, with perivascular neutrophilic infiltrate in the dermis, in contrast to lymphocytic and eosinophilic infiltrates of classical urticaria. ${ }^{2,9}$ Blood neutrophilia and an increase in acute phase proteins during exacerbations are common. ${ }^{16,17}$

FCAS is the mildest of all CAPS. ${ }^{18,19}$ Clinical manifestations usually appear within the first six months of life and are characterized by an atypical urticarial rash with painful and non-pruritic maculopapular lesions, associated with fever peaks., ${ }^{5,11,12,14}$ Attacks usually occur following exposures to cold or decreases in temperature including air conditioning and cool damp conditions. ${ }^{20}$ They last less than 24 hours and patients have other associated symp- toms, like arthralgias, conjunctivitis, headache, myalgias and extreme thirst. ${ }^{7,11,13,14}$ Amyloidosis is a rare long-term complication (Chart 1)..$^{18,21}$

The Muckle Well Syndrome manifests during childhood and adolescence by recurrent febrile episodes associated with vanishing non-pruritic urticarial rash, arthralgia, myalgia and conjunctivitis., ${ }^{5,11,13,14,22}$ Fever may not be present. ${ }^{2}$ Symptoms tend to last longer than in FCAS (12 to 36 hours). In general, cutaneous eruption is the first symptom to be noticed and might be a burning sensation. ${ }^{2} \mathrm{~A}$ progressive sensorineural hearing loss begins in childhood and often results in complete deafness by adolescence. Secondary amyloidosis affects $25 \%$ of patients and can result in chronic renal insufficiency. ${ }^{23}$

NOMID is a clinical expression of the most severe form of mutation in NLRP3, which can be sporadic or autosomal-dominant. 7,11,12,14 The triad of skin rash, severe arthropathy, and central nervous system disorders characterize NOMID. ${ }^{18}$ It appears immediately after birth and manifestations are chronic with periods of exacerbations. ${ }^{3,7,14}$ The patients have severe fever outbreaks associated with persistent cutaneous manifestations initially in the form of polymorphic urticarial rash or a migratory and non-pruriginous maculopapular rash. 5,711,12,14 Patients also show abnormal facial features, such as flattening of the nasal bridge, macrocephaly, frontal bossing, and protruding eyes. ${ }^{18}$ There can also coexist musculoskeletal symptoms and impairment of the central nervous system, as well as longterm complications that modify the prognosis of this disease (Chart 1). The mortality is high in untreated patients, $20 \%$ of patients die before reaching adulthood. ${ }^{3,21}$

Familial cold autoinflammatory syndrome type 2 (FCAS 2) or NLRP12-associated hereditary periodic fever syndrome

This is a rare autosomal dominant disease, due to mutations in NLRP2, gene responsible for the synthesis of NLRP12 pro-

CHART 1: Urticarial exanthema as skin manifestation in various autoinflammatory syndromes

\begin{tabular}{|c|c|c|c|}
\hline \multicolumn{2}{|l|}{ Disease } & \multirow{2}{*}{$\begin{array}{l}\text { Possible skin lesion } \\
\text { Atypical, migratory } \\
\text { rash or less frequently } \\
\text { maculopapular urticar- }\end{array}$} & \multirow{2}{*}{$\begin{array}{l}\text { Systemic involvement } \\
\text { Arthralgias, conjunctivitis, thirst, headache and nau- } \\
\text { sea, severe fatigue, secondary amyloidosis (less than } \\
5 \% \text { of patients) }\end{array}$} \\
\hline \multirow{3}{*}{$\begin{array}{l}\text { Cryopyrin-asso- } \\
\text { ciated periodic } \\
\text { syndromes (CAPS) }\end{array}$} & $\begin{array}{l}\text { Familial cold-induced auto-in- } \\
\text { flammatory syndrome (FCAS) }\end{array}$ & & \\
\hline & Muckle-Wells syndrome (MWS) & ia-like rash & $\begin{array}{l}\text { With or without fever, conjunctivitis, arthralgia, arthri- } \\
\text { tis, hearing loss }(40 \%) \text { and amyloidosis }(25-30 \%)\end{array}$ \\
\hline & $\begin{array}{l}\text { CINCA-NOMID syndrome } \\
\text { (Chronic infantile neurologic cu- } \\
\text { taneous and articular syndrome, } \\
\text { also know as Neonatal onset mul- } \\
\text { tisystem inflammatory disease) }\end{array}$ & & $\begin{array}{l}\text { Deforming osteoarthropathy, chronic aseptic menin- } \\
\text { gitis, cerebral atrophy, enlargement of the ventricles, } \\
\text { intracranial hypertension, sensorineural hearing loss, } \\
\text { chronic papilledema, optic nerve atrophy, lymphade- } \\
\text { nopathy and hepatosplenomegaly, facial morphologi- } \\
\text { cal changes, growth and mental retardation, amyloido- } \\
\text { sis }(20 \%)\end{array}$ \\
\hline \multicolumn{2}{|c|}{$\begin{array}{l}\text { Familial cold autoinflammatory syndrome type } 2 \text { (FCAS } \\
\text { 2) or NLRP12-associated hereditary periodic fever syn- } \\
\text { drome }\end{array}$} & Urticarial rash & $\begin{array}{l}\text { Arthralgias, headache, sensorineural hearing loss, lym- } \\
\text { phadenopathy, abdominalgia }\end{array}$ \\
\hline \multicolumn{2}{|l|}{ Schnitzler syndrome } & Urticarial rash & $\begin{array}{l}\text { Fever, arthralgia, arthritis, bone pain, bone density, } \\
\text { lymphadenopathy and hepatosplenomegaly, Walden- } \\
\text { strom macroglobulinemia, lymphoplasmacytic lym- } \\
\text { phoma, multiple myeloma and B-cell lymphoma of } \\
\text { marginal zone, secondary amyloidosis }\end{array}$ \\
\hline
\end{tabular}


tein, which acts as a regulator of the immunity against pathogenic agents. ${ }^{3,7,11}$ It has a clinical phenotype between FCAS and MWS. ${ }^{24}$ Patients have recurrent febrile episodes from the first years of life, triggered by exposure to cold, lasting five to ten days, associated with headache, arthralgia, urticaria, thrush, sensorineural hearing loss, lymphadenopathy, and abdominalgia with rise of acute phase proteins (Chart 1). $3,7,11,14,25$

\section{Schnitzler syndrome}

Schnitzler syndrome is a rare condition that usually arises in the fourth decade of life. ${ }^{26}$ It is characterized by the major diagnostic criteria of non-pruriginous urticarial rash (Figure 1) and monoclonal gammopathy IgM or IgG. At least two minor criteria must be present. ${ }^{10,14,26}$ It includes intermittent episodes of fever, arthralgia or arthritis, bone pain, bone densification, lymphadenopathy, hepatosplenomegaly, leukocytosis, and acute phase protein elevation. 10,12,14,26 The frequency of exacerbations is variable, and symptoms can be daily or annual. It presents with clinical similarities to CAPS, particularly to Muckle Wells syndrome, which is also associated with monoclonal gammopathy IgM. ${ }^{7,10,12,14}$ Later the patients may develop secondary amyloidosis and lymphoproliferative disorders (Chart 1). Wheals usually do not vanish within 2 hours and often persist over 24 hours.

The pathophysiology of Schnitzler syndrome remains unclear, but mechanisms of autoimmunity and autoinflammation seem to play an important role, due to the presence of autoantibodies of the IgG3 class against the alpha chain $(\alpha)$ of cellular proteins, high affinity autoantibodies IgG2 for the IgE receptor (FceRI) and autoantibodies against IL-1 $\alpha$. Interferon alpha (IFN- $\alpha$ ), which increases the expression of the IL-1 receptor antagonist, and the IL-1 antagonist anakinra induce symptomatic improvement in the patients, highlighting the importance of IL-1 in the pathogenesis of the disease. ${ }^{26}$ Recently a mutation in NLRP3 has been detected in some

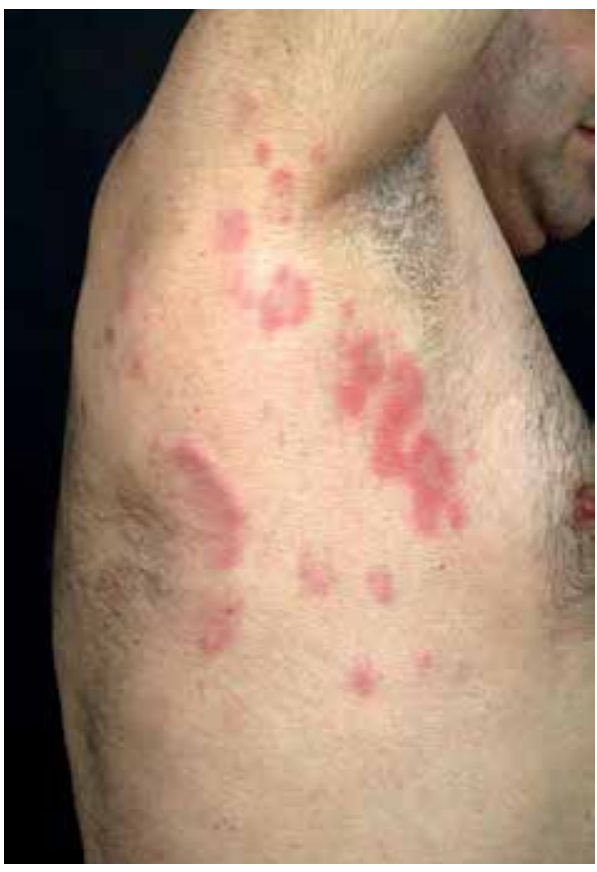

FIGURE 1: Schnitzler Syndrome of the patients suggesting a role of the inflammasome in the pathogenesis of the disease, which might lead to the inclusion of this disease in CAPS group despite the absence of mutations in other patients. ${ }^{12}$ To date, no treatment is specifically approved for Schnitzler syndrome and spontaneous remissions are extremely rare. ${ }^{14}$

\section{DERMO-HYPODERMITIS}

\section{Familial Mediterranean fever (FMF)}

The Familial Mediterranean Fever is a rare autosomal recessive disease. ${ }^{11,12,27}$ Mutations in the MEFV gene (MEditerranean FeVer), located on chromosome 16 (16p13), encoding pyrin, lead to an insufficient inhibitory regulation of the NLRP3 inflammasome, increased production of interleukin-1ß (IL -1ß), IL-18, IL-33 and stimulated apoptosis. ${ }^{3,11,12,27,28}$ Incomplete penetrance and variable clinical expression is seen among FMF patients, even in those who have the same mutation. ${ }^{18}$

The disease usually appears before the age of 20 and can even, in two-thirds of the patients, appear before they are $5 .{ }^{11,12}$ There are three main phenotypes: Type 1, with classical symptoms and starting at early ages; Type 2 , characterized by reactive AA amyloidosis as a first manifestation; and Type 3, in which mutations in the MEFV gene are detected in the absence of signs and symptoms of the disease. ${ }^{11,25,29}$

The disorder is characterized by recurrent episodes of fever, associated with abdominal pain and arthritis that last from 1 to 3 days. ${ }^{27,30,31}$ Articular involvement is present in up to $75 \%$ of patients. Most of the patients have also constitutional and emotional symptoms. ${ }^{11,27}$

Cutaneous manifestations usually manifest in the form of dermo-hypodermitis (Chart 2). 5,12,25,32,33 The most common cutaneous presentation is erysipelas-like erythema, reported in $7 \%$ to $40 \%$ and characterized by lower limb erythematous and rash that are frequently misdiagnosed as cellulitis. ${ }^{27}$ It comprises erythematous plaques with 10 to $15 \mathrm{~cm}$ in diameter in the pre-tibial region and around the medial malleolus of the foot. ${ }^{5,12,27}$ Diffuse palmoplantar erythema can also be present. Other manifestations such as vasculitis, similar to polyarteritis nodosa - Henoch-Schoenlein purpura and angioedema can also occur. . $^{5,12,13,25}$

Proteinuria is suggestive of secondary systemic amyloidosis, which is a severe and potentially lethal complication. ${ }^{11,25,27}$ In the laboratory, an increase of inflammatory parameters is found, with neutrophilic leukocytosis, increased C-reactive protein, fibrinogen and serum amyloid protein. ${ }^{13,34}$

\section{TNF receptor associated periodic syndrome (TRAPS)}

This is a rare autosomal dominant autoinflammatory syndrome. ${ }^{3,11,35}$ It is associated with mutations in the receptor TNFRSF1A, which encodes the p55 tumor necrosis factor (TNF), leading to the absence of the anti-inflammatory signals and to a persistent pro-inflammatory state with secretion of IL1, IL8 and IL12.,7,12,35 It usually appears after childhood, but before 20 years of age. ${ }^{12}$

It is characterized by recurrent episodes of fever lasting up to three weeks, accompanied by periorbital edema, conjunctivitis, abdominal pain, arthralgia, myalgia and dermo-hypodermitis. ${ }^{3,5,7,12,35}$

The cutaneous manifestations occur in approximately $80 \%$ 
of patients in the acute phase of the disease. ${ }^{12,36}$ The most frequent skin lesion, seen in $40 \%$ of the cases, is a centrifugal migratory erythematous rash, warm and painful, in an area of overlapping myalgia., $13,14,18,36$ Other presentations include erysipelas-like erythema, edematous plaques, similar to cellulitis, panniculitis and urticarial lesions on the limbs and trunk. Reticulated discrete spots or serpiginous and annular plaques may also occur. ${ }^{7,32,36,37}$ The histopathology of skin lesions is characterized by perivascular lymphocytic and monocytic dermal infiltrate. ${ }^{7,35}$

Approximately one-fourth of the patients develop secondary systemic amyloidosis, the most serious complication of TRAPS, which determines the prognosis. ${ }^{7,12}$ Stress and trauma can act as triggers, and other TNF receptor antagonists, beyond those used in the treatment, like infliximab and adalimumab, may cause paradoxical aggravation of inflammatory response signals (Chart 2). ${ }^{5,6,11,35}$

\section{Mevalonate kinase deficiency (MKD)}

MKD is an autosomal recessive disease that results from insufficient activity of mevalonate kinase, involved in the biosynthesis of cholesterol and isoprenoids due to mutations in the MVK gene. ${ }^{3,33,38}$ In hyperimmunoglobulinemia D with periodic fever syndrome (HIDS), the milder form of the disease, MVK activity is reduced to 1 to $10 \%$ of normal, whereas in mevalonic aciduria, the most severe form, this activity is below $1 \% \cdot{ }^{39,40}$ Both are considered different spectrum of the same disease. ${ }^{38}$

It is characterized by recurrent high fever associated with abdominal pain, diarrhea, nausea, arthritis, arthralgia, headache and dermo-hypodermitis (Chart 2). 3,5,11,12,32,39,41 Fever episodes last 3 to 7 days and typically recur every 4 to 6 weeks and can be induced by emotional and physical stress, vaccines, infections and menses. ${ }^{7,2,25,42}$ Clinical manifestations begin usually during the first year of life and the symptoms usually become less pronounced in adulthood.,11,12

Cutaneous manifestations typically arise as maculopapular or morbilliform rash, or less usually as urticarial rash and erythema nodosum. ${ }^{5,7,12,14,25,41,43}$ In $50 \%$ of patients oral or bipolar aphthosis coexist. ${ }^{5,7,12,13,41}$ Small erythematous patches, papules, nodules or plaques clinically similar inflammatory cellulitis, petechiae or purpura may occur, resembling Henoch-Schoenlein purpura, erythema elevatum diutinum or Sweet syndrome. . $25,37,43$

Patients with mevalonic aciduria also exhibit developmental delay, severe mental retardation, ataxia, hypotonia, cerebellar atrophy, dysmorphic facies, myopathy and cataracts. ${ }^{7,11,14,25,44}$ Secondary systemic amyloidosis is found in less than $3 \%$ of the cases. ${ }^{7,12}$

In laboratory analyses leukocytosis, neutrophilia, increase in acute phase proteins can be found as well as increased polyclonal immunoglobulin $\mathrm{D}(\operatorname{IgD})$ and $\mathrm{A}(\operatorname{IgA}){ }^{7,11,28,32,45}$ However, as $\operatorname{IgD}$ is not always elevated in serum, a normal IgD does not exclude MKD. ${ }^{46}$ The increased urinary excretion of mevalonic acid during crises is the key to diagnosis.

Systemic juvenile idiopathic arthritis (SJIA) and Adult-onset Still's disease (AOSD)

SJIA and AOSD are rare inflammatory diseases, which are distinguished by the age of onset. The first one appears in children under 16 years whereas Still's disease usually appears until 35 years of age. There is growing evidence that these may be considered autoinflammatory diseases, in which the final common pathway is triggered by persistent activation of innate immunity, verifying increased secretion of IL-1ß by monocytes. ${ }^{15,29}$ There is an increase in acute phase proteins and in ferritin levels, with lack of positive autoantibodies or autoantigen specific T cells. ${ }^{7,12,14,15,34,37}$

The classic triad includes daily spiking fevers $\left(\geq 39^{\circ} \mathrm{C}\right)$, juvenile idiopathic arthritis or rheumatoid rash, and polyarthritis. ${ }^{48}$ The fever and arthritis are followed by a not fixed, evanescent salmon-colored, maculopapular rash, generalized lymphadenopathy, hepatosplenomegaly and polyserositis (Chart 2). ${ }^{12,14,15}$ Other cuta-

CHART 2: Dermo-hypodermitis as skin manifestation in various autoinflammatory syndromes

\begin{tabular}{|c|c|c|c|}
\hline Disease & Possible skin lesion & Systemic involvement & Therapeutic options \\
\hline $\begin{array}{l}\text { Familial Mediterranean } \\
\text { fever (FMF) }\end{array}$ & $\begin{array}{l}\text { Erysipelas-like erythema and } \\
\text { rarely diffuse palmoplantar } \\
\text { erythema, vasculitis and } \\
\text { angioedema }\end{array}$ & $\begin{array}{l}\text { Fever, peritonitis, pleuritis, abdominalgia, } \\
\text { arthralgias, aseptic meningitis, spleno- } \\
\text { megaly and retinopathy, secondary amy- } \\
\text { loidosis }\end{array}$ & $\begin{array}{l}\text { Colchicine, anakinra in thera- } \\
\text { py-resistant patients }\end{array}$ \\
\hline $\begin{array}{l}\text { TNF receptor associated } \\
\text { periodic syndrome } \\
\text { (TRAPS) }\end{array}$ & $\begin{array}{l}\text { Painful erythematous rash with } \\
\text { edematous migrant plaques; ur- } \\
\text { ticarial lesions; erysipelas-like } \\
\text { erythema and periorbital edema }\end{array}$ & $\begin{array}{l}\text { Fever, periorbital edema, conjunctivitis, } \\
\text { abdominalgia, arthralgia, myalgia, seros- } \\
\text { itis and centrifugal muscle edema and } \\
\text { chronic fasciitis }\end{array}$ & $\begin{array}{l}\text { Nonsteroidal anti-inflammato- } \\
\text { ry drugs (NSAID), etanercept, } \\
\text { anakinra }\end{array}$ \\
\hline $\begin{array}{l}\text { Mevalonate kinase } \\
\text { deficiency (MKD) }\end{array}$ & $\begin{array}{l}\text { Morbilliform or maculopapular } \\
\text { rash; urticarial rash; erythema } \\
\text { nodosum; aphtosis and petechiae } \\
\text { amongst others }\end{array}$ & $\begin{array}{l}\text { Fever, abdominalgia, diarrhea, nausea, } \\
\text { arthritis, headache, lymphadenopathy, } \\
\text { hepatosplenomegaly, tendinitis and my- } \\
\text { algias }\end{array}$ & $\begin{array}{l}\text { NSAID, corticosteroids, etaner- } \\
\text { cept, anakinra, canakimumab, } \\
\text { simvastatin }\end{array}$ \\
\hline $\begin{array}{l}\text { Systemic juvenile } \\
\text { idiopathic arthritis(SJIA) } \\
\text { and Adult-onset Still's } \\
\text { disease (AOSD) }\end{array}$ & $\begin{array}{l}\text { Not fixed, evanescent salm- } \\
\text { on-colored, maculopapular rash, } \\
\text { urticarial rash or persistent pru- } \\
\text { ritic papules and plaques }\end{array}$ & $\begin{array}{l}\text { Fever, arthritis, generalized lymphade- } \\
\text { nopathy, hepatosplenomegaly, polyseros- } \\
\text { itis, liver failure, amyloidosis, tendency } \\
\text { to infections, disseminated intravascular } \\
\text { coagulation and macrophage activation } \\
\text { syndrome }\end{array}$ & Tocilizumab, anakinra \\
\hline
\end{tabular}


neous manifestations include urticarial rash and persistent pruritic papules and plaques. ${ }^{14}$ Although the neutrophilic urticarial dermatosis may be present in Still's disease with onset in adulthood, in SJIA this has not been identified, despite the clinical description of a characteristic evanescent rash of juvenile idiopathic arthritis mimicking neutrophil urticarial dermatosis. ${ }^{16}$ They respond favorably to inhibition of interleukins and steroid use, but there may be increased mortality from medical complications. ${ }^{15}$

\section{NEUTROPHILIC DERMATOSIS}

\section{PAPA syndrome}

This autosomal dominant hereditary autoinflammatory syndrome is caused by a mutation on the PSTPI1P gene, which encodes CD2BP1 (1-binding protein CD2) also known as PSTPI1P. $5,7,12,49-51$ This protein binds to pyrin, the mutated protein in FMF. Both of them are part of the inflammasome NLRP3 on granulocytes and monocytes. The mutated PSTPI1P suffers hyperphosphorylation, increasing the binding affinity to pyrin. This leads to the lost of the inhibitory effect on the inflammasome and on the signaling pathway proinflammatory caspase 1 , predisposing to a dependent inflammatory response of IL-1B. ${ }^{50,51}$ It usually appears before the age of 5 with recurrent episodes of erosive sterile arthritis, especially of the knees, elbows and ankles, leading to joint destruction. ${ }^{10-13,18,28,49}$ Other less frequent clinical manifestations are recurrent otitis, pharyngeal papillomatosis, lymphadenopathy, splenomegaly, hypergammaglobulinemia, hemolytic anemia and $\mathrm{T}$ cell large granular lymphocytosis. ${ }^{52}$

Cutaneous manifestations are episodic and recurrent, appear at puberty and, contrary to arthritis symptoms, which tends to regress, they persist into adulthood (Chart 3). ${ }^{10,12,50}$ They include nodular cystic acne with scar formation, pyoderma gangrenosum, sterile abscesses at injection sites and pathergy (Figure 2). ${ }^{7,10-12,49,51}$ There is a localized form, with ulcers on the lower extremities and a multifocal form, with diffuse cutaneous involvement. ${ }^{10,12,13}$ Histologically, the lesions consist of sterile neutrophilic infiltrate. The choice of treatment depends on the predominant clinical manifestation (Chart 3).

\section{Deficiency of the interleukin-1-receptor antagonist (DIRA)}

DIRA is an autosomal recessive, autoinflammatory disease caused by deletion of the IL1RN gene located on chromosome 2 that leads to the complete absence of the interleukin-1-receptor antagonist (IL-1RA) and consequently to the increase of pro-inflammatory

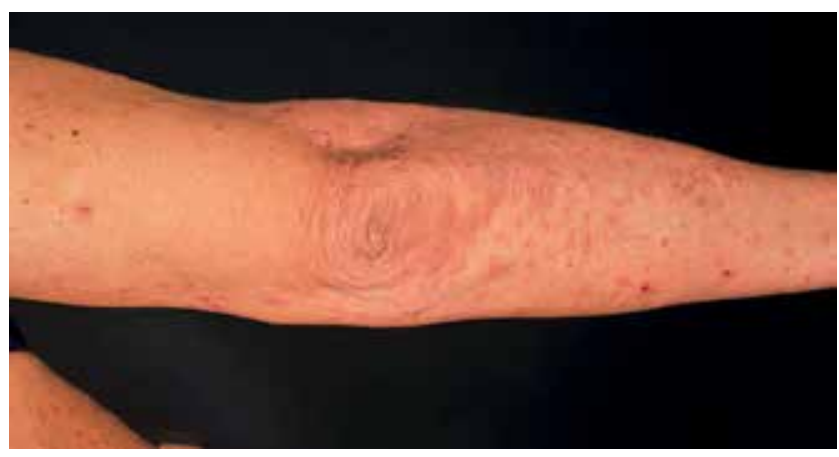

Figure 2: PAPA syndrome

CHART 3: Neutrophilic dermatosis as skin manifestation in various autoinflammatory syndromes

\begin{tabular}{|c|c|c|c|}
\hline Disease & Possible skin lesion & Systemic involvement & Therapeutic options \\
\hline $\begin{array}{l}\text { PAPA syndrome } \\
\text { (acronym for pyogenic arthritis, pyoder- } \\
\text { ma gangrenosum and acne) }\end{array}$ & $\begin{array}{l}\text { Nodular-cystic acne and } \\
\text { pyoderma gangrenosum }\end{array}$ & Sterile erosive arthritis & $\begin{array}{l}\text { Corticosteroid therapy, } \\
\text { infliximab, anakinra }\end{array}$ \\
\hline $\begin{array}{l}\text { Deficiency of the interleukin-1-receptor } \\
\text { antagonist (DIRA) }\end{array}$ & $\begin{array}{l}\text { Pustulosis, localized or dif- } \\
\text { fuse }\end{array}$ & $\begin{array}{l}\text { Periostitis, multifocal osteomyelitis and } \\
\text { joint swelling, stomatitis, hepatospleno- } \\
\text { megaly, conjunctivitis and vasculitis }\end{array}$ & Anakinra \\
\hline Majeed syndrome & $\begin{array}{l}\text { Psoriasiform lesions, palmo- } \\
\text { plantar pustulosis, acne and } \\
\text { pyoderma gangrenosum }\end{array}$ & $\begin{array}{l}\text { Recurrent multifocal osteomyelitis, chro- } \\
\text { nic congenital dyserythropoietic anemia, } \\
\text { growth retardation }\end{array}$ & $\begin{array}{l}\text { Nonsteroidal anti-in- } \\
\text { flammatory drugs, } \\
\text { corticosteroid therapy }\end{array}$ \\
\hline $\begin{array}{l}\text { SAPHO syndrome (acronym for syno- } \\
\text { vitis, acne, pustulosis, hyperostosis, and } \\
\text { osteitis) }\end{array}$ & $\begin{array}{l}\text { Acne conglobata or fulmi- } \\
\text { nans, pustulosis palmoplan- } \\
\text { taris and rarely psoriasiform } \\
\text { lesions and pyoderma gan- } \\
\text { grenosum }\end{array}$ & Synovitis, hyperostosis and osteitis & \\
\hline $\begin{array}{l}\text { Chronic recurrent multifocal osteomy- } \\
\text { elitis (CRMO) }\end{array}$ & $\begin{array}{l}\text { Psoriasiform lesions, palmo- } \\
\text { plantar pustulosis }\end{array}$ & $\begin{array}{l}\text { Multifocal osteomyelitis, association with } \\
\text { spondyloarthropathy, inflammatory bow- } \\
\text { el disease and Sweet syndrome }\end{array}$ & $\begin{array}{l}\text { Anti-inflammatory } \\
\text { drugs, corticosteroids, } \\
\text { methotrexate, sul- } \\
\text { fasalazine, and inflixi- } \\
\text { mab (TNF- } \alpha \text { inhibitor) }\end{array}$ \\
\hline Sweet's syndrome & $\begin{array}{l}\text { Erythematous nodules or } \\
\text { plaques and rarely pustular } \\
\text { dermatosis or ulcerated and } \\
\text { bullous lesions }\end{array}$ & $\begin{array}{l}\text { Hematological malignancies, rheumatoid } \\
\text { arthritis, inflammatory bowel disease and } \\
\text { eye involvement }\end{array}$ & $\begin{array}{l}\text { Corticosteroids, IL-1 } \\
\text { blockers, Kineret }\end{array}$ \\
\hline
\end{tabular}


cytokines IL-1 $\alpha$ and IL-1 $\beta .^{7,-12,17}$ It resembles NOMID: begins in the perinatal period with arthralgia and joint swelling, neutrophilic infiltrate in the dermis and increased acute phase proteins. ${ }^{9,17}$

It is characterized by plaques with overlying pustules, simulating generalized pustular psoriasis, with neutrophils infiltrating the epidermis. ${ }^{9,17}$ It appears at birth or during the first 2 months of age. ${ }^{18}$ Nail changes are common. Association with pyoderma gangrenosum has been described. ${ }^{12}$ The cutaneous pustulosis affects all children with the disease and ranges from localized to severe diffuse pustulosis or ichthyosiform lesions. ${ }^{17}$ It is also associated with multifocal periostitis and osteomyelitis. ${ }^{7,10-12}$

SAPHO syndrome and Chronic Recurrent Multifocal Osteomyelitis (CRMO)

SAPHO syndrome is characterized by synovitis, acne, pustulosis, hyperostosis and osteitis and CRMO, which affects the long bones, has been considered its pediatric variant (Figure 3). ${ }^{7,53}$ The characteristic cutaneous manifestations of SAPHO syndrome are severe acne (conglobata and fulminans) and pustulosis palmoplantaris (PPP). ${ }^{12,54}$ Severe acne can affect around one-fourth of patients, and PPP $50-75 \%$ of patients. ${ }^{54}$ In CRMO, skin manifestations are less common. It manifests as recurrent multifocal sterile inflammatory bone lesions with or without fever, associated with pustulosis, severe acne and psoriasiform lesions (Chart 3). ${ }^{3,51,55,56}$

Its etiology remains unknown and shares some etiopathogenic mechanisms with other autoinflammatory diseases like Receptor Antagonist Deficiency of IL-1 and Majeed syndrome. ${ }^{3,51}$ There have been recent hints at a participation of a proline-serine-threonine phosphatase-interacting protein 2 (Pstpip2) in the pathogenesis of CRMO. Missense mutation (L98P) of Pstpip2 in mice leads to a disease that is phenotypically similar to CRMO. Studies about these conditions have revealed an inflammasome-independent role for IL-1 $\beta$ in disease progression, which provides a rationale for directly targeting IL-1RI or IL-1 $\beta$ as a therapeutic strategy in CRMO. ${ }^{57}$ Nevertheless, SAPHO syndrome is associated with high serum levels of proinflammatory cytokines, such as IL-8, IL-18 and TNF- $\alpha$, and these cytokines can be responsible for the maintenance of the clinical manifestations. ${ }^{58}$

Diagnostic criteria include: two or more typical bone lesions as osteolysis with surrounding sclerosis in conventional radiogra-

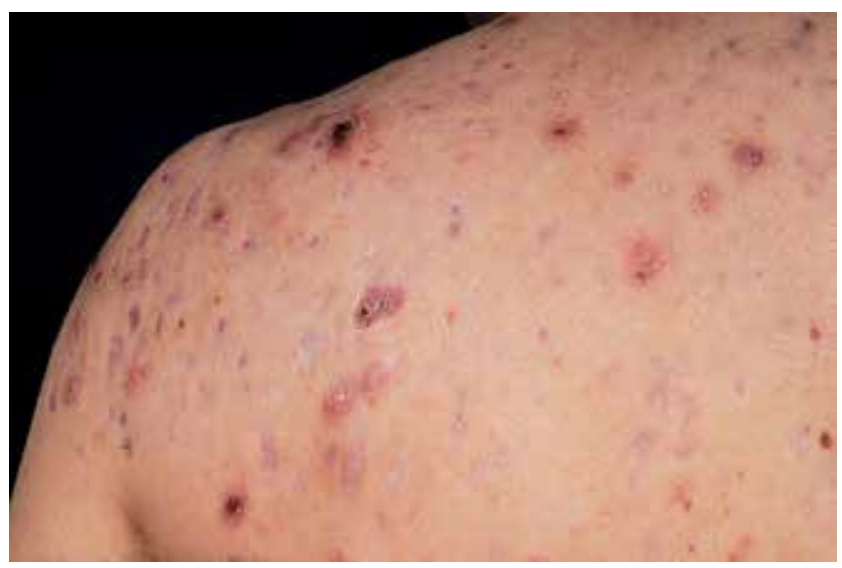

FigURE 3: SAPHO syndrome phy, lasting less than six months, typical histological features in bone biopsy and less than 18 years of age at diagnosis. ${ }^{13}$

\section{Majeed syndrome}

Majeed syndrome is a rare, autosomal recessive autoinflammatory disease, associated with a homozygous mutation in LPIN2 gene. ${ }^{34,56}$ Usually it appears before the age of two and is characterized by a triad of chronic multifocal recurring osteomyelitis, congenital dyserythropoietic anemia and neutrophilic dermatosis (Chart 3)..$^{13,56}$

Phenotypically it is more severe than the CRMO: the recurrence rate of bone inflammation is higher, the remissions are less frequent and the disease persists in the adult age.$^{56}$ Congenital dyserythropoietic anemia with hypochromia and microcytosis is present, in contrast to the macrocytic or normocytic anemia that usually characterizes the congenital dyserythropoietic anemia. ${ }^{11,13,56}$ Individuals with Majeed syndrome have also growth retardation with short stature. ${ }^{59}$ Cutaneous manifestations include psoriasiform lesions, palmoplantar pustulosis, acne and pyoderma gangrenosum. ${ }^{13,50}$ Sweet's syndrome with typical neutrophilic infiltrates and pustulosis can be similar to Majeed syndrome.,.$^{5,1126}$

\section{Sweet's syndrome (SS)}

SS was initially described as an acute febrile neutrophilic dermatosis. The pathogenesis of the disease is not fully understood. The association with infections, autoimmune diseases, neoplasms and drugs suggests a hypersensitivity reaction. Cytokines appear to play an etiologic role in the development of lesions and symptoms. ${ }^{60}$ There are no detectable autoantibodies or specific T cells. ${ }^{10}$

Fever is the most common sign. Eye involvement can be the initial presentation. Arthritis or arthralgia occurs in up two-thirds of the patients. ${ }^{60}$ Cutaneous manifestations occur in the form of painful nodules or erythematous cutaneous plaques, which are characterized histologically by neutrophil infiltrate in the upper dermis. ${ }^{10}$ It can also presents as a pustular dermatosis or with ulcerated and bullous lesions. ${ }^{60}$ It arises often associated with hematologic malignancies, rheumatoid arthritis and inflammatory bowel disease (Chart 3). Laboratory findings suggestive of SS include peripheral leukocytosis with neutrophilia and elevated erythrocyte sedimentation rate or C-reactive protein. ${ }^{60}$

\section{GRANULOMATOUS DERMATITIS}

Familial Blau Syndrome and Sporadic Early-onset Sarcoidosis

The Blau Syndrome is a granulomatous, autosomal dominant disease associated with a mutation in the NATCH domain of the NOD2 / CARD15 gene. ${ }^{11,13,32}$ Early-onset sarcoidosis shares the clinical manifestations, but happens as a sporadic condition. ${ }^{18}$ The two disorders were initially described as different clinical entities, however the association of mutations in the NOD2 / CARD15 gene in some patients with early-onset sarcoidosis have led some authors to consider the Blau syndrome as the familiar form of sarcoidosis and early-onset sarcoidosis as the sporadic form of the same disease. ${ }^{61,62}$ Different from sarcoidosis, hilar lymph nodes and lungs are not affected. ${ }^{7,37,62}$

The onset is usually before 4 years of age and is character- 
ized by the triad of early-onset of polyarticular synovitis, skin rash and eye involvement with recurrent anterior uveitis. 12,32,41,61,62 Skin manifestations are usually the first symptom of the disease and appear as maculopapular rash or multiple subcutaneous nodules, with symmetrical presentation located mainly on the trunk and extremities. ${ }^{27,41,45,61}$ The papules, small and with variable color (from yellow to brownish red), typically are grouped and may converge. The papular rash occurs intermittently and can resolve spontaneously leaving a scar. ${ }^{61,62}$ Other cutaneous findings described are panniculitis resembling erythema nodosum and leukocytoclastic vasculitis. ${ }^{63}$ Systemic impairment may still occur (Chart 4).

\section{BIPOLAR APHTHOSIS}

\section{Behçet's disease}

Behçet's disease is a recurring systemic inflammatory disease, with unknown etiology characterized by the triad: oral aphthous ulcers, genital ulcers and uveitis (Chart 5). The disease usually appears in the third decade of life and affects both genders equally. The most serious manifestations tend to occur more often in men, particularly amaurosis, large vessel vasculitis, cerebrovascular, lung and gastrointestinal impairment. ${ }^{64}$ The disease progresses during exacerbation and remission periods. ${ }^{3,64}$

Bipolar aphthosis with oral aphthous ulcers and genital lesions are the major symptoms of the disease (Figure 4). ${ }^{12,64}$ In adults, the classification criteria include the presence of recurrent oral ulcers, associated with at least one of the following symptoms: recurrent genital ulcers, uveitis with ocular and cutaneous impairment or positive pathergy tests. ${ }^{3,65}$ Other cutaneous manifestations include pseudofolliculitis, papulopustular lesions, similar to acneiform nodules and erythema nodosum lesions. Systemic involvement (Chart 5) is characterized by vasculitic lesions associated with tissue infiltration by neutrophils and T lymphocytes. ${ }^{10}$

\section{Periodic fever Aphthous pharyngitis and cervical adenop-} athy (PFAPA)

This is a chronic disease of unknown etiology, characterized by recurrent episodes of high fever accompanied by pharyn-

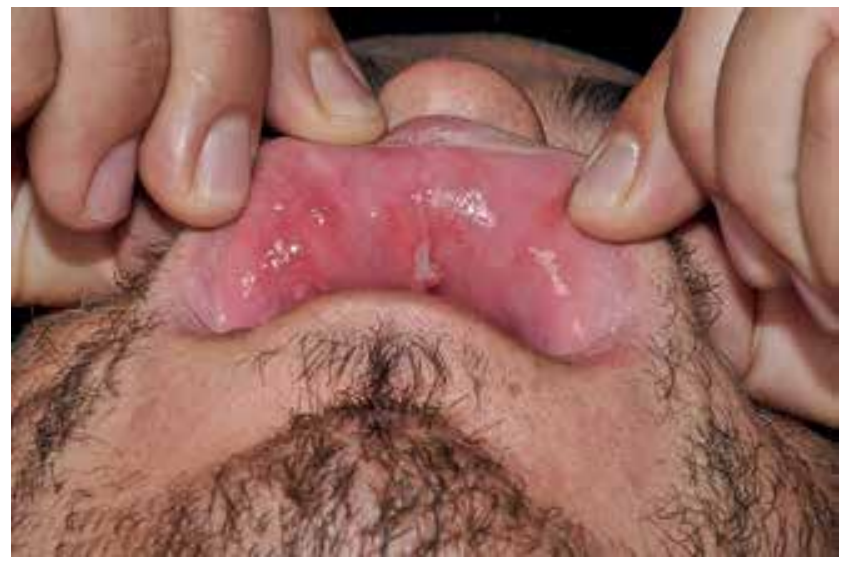

Figure 4: Behçet's disease

Сhart 4: Granulomatous dermatitis as skin manifestation in various autoinflammatory syndromes

\begin{tabular}{|c|c|c|c|}
\hline Disease & Possible skin lesion & Systemic involvement & Therapeutic options \\
\hline $\begin{array}{l}\text { Familial Blau } \\
\text { syndrome and } \\
\text { sporadic early-on- } \\
\text { set sarcoidosis }\end{array}$ & $\begin{array}{l}\text { Granulomatous papular } \\
\text { erythematous rash, and } \\
\text { rarely, panniculitis and } \\
\text { leukocytoclastic vasculitis }\end{array}$ & $\begin{array}{l}\text { Symmetric polyarthritis, polyarthritis, deformans with } \\
\text { camptodactyly, joint swelling and effusion of synovi- } \\
\text { al fluid, recurrent uveitis, glaucoma, cataracts, fever, } \\
\text { granulomatous vasculitis, renal and hepatic granu- } \\
\text { lomatosis, and lymphadenopathy pneumonitis }\end{array}$ & $\begin{array}{l}\text { Corticosteroid therapy, ciclo- } \\
\text { sporin A, methotrexate, myco- } \\
\text { phenolate mofetil, TNF inhibi- } \\
\text { tors, anakinra, thalidomide }\end{array}$ \\
\hline Crohn's disease & $\begin{array}{l}\text { Erythema nodosum, pyo- } \\
\text { derma gangrenosum, oral } \\
\text { aphthosis }\end{array}$ & Gastrointestinal noncaseating granulomas & $\begin{array}{l}\text { Corticosteroid, mesalazine, } \\
\text { azathioprine, infliximab and } \\
\text { intravenous immunoglobulin }\end{array}$ \\
\hline
\end{tabular}

CHART 5: Bipolar aphthosis as skin manifestation in various autoinflammatory syndromes

\begin{tabular}{|c|c|c|c|}
\hline Disease & Possible skin lesion & Systemic involvement & Therapeutic options \\
\hline Behçet's disease & $\begin{array}{l}\text { Oral and genital aphthous } \\
\text { ulcers, erythema nodosum, } \\
\text { pseudofolliculitis, papulopus- } \\
\text { tular lesions, acneiform lesions } \\
\text { and erythema nodosum }\end{array}$ & $\begin{array}{l}\text { Uveitis, amaurosis, large vessel vasculitis, cer- } \\
\text { ebrovascular and gastrointestinal involvement } \\
\text { and pulmonary vascular disease }\end{array}$ & $\begin{array}{l}\text { Corticosteroid, } \begin{array}{r}\text { colchicine, } \\
\text { azathioprine, methotrexate, } \\
\text { cyclosporine, thalidomide, } \\
\text { anakinra }\end{array}\end{array}$ \\
\hline $\begin{array}{l}\text { Periodic fever, } \\
\text { aphthous pharyn- } \\
\text { gitis and cervica } \\
\text { lymphadenopathy } \\
\text { (PFAPA) }\end{array}$ & $\begin{array}{l}\text { Oral and genital aphthous } \\
\text { ulcers and less commonly er- } \\
\text { ythema on the trunk, palmo- } \\
\text { plantar macules or purpura, } \\
\text { acneiform lesions and pyoder- } \\
\text { ma gangrenosum }\end{array}$ & $\begin{array}{l}\text { Pharyngitis, and cervical lymphadenopathy, } \\
\text { headache, abdominal pain, nausea, vomiting, } \\
\text { myalgia, arthritis, arthralgia, splenomegaly, } \\
\text { slight increase in IgM, IgD and IgA, leukocytosis } \\
\text { and slight increase in acute phase proteins }\end{array}$ & $\begin{array}{l}\text { Corticosteroid, cimetidine, } \\
\text { colchicine, anakinra, tonsillec- } \\
\text { tomy and adenoidectomy }\end{array}$ \\
\hline
\end{tabular}


gitis, cervical lymphadenopathy and aphthous stomatitis (Chart 5). ${ }^{3,13,66}$ Other symptoms include: headache, abdominal pain, nausea, vomiting, myalgia, arthritis, arthralgia, splenomegaly (Chart 5). ${ }^{13,66}$ During fever periods, leukocytosis and increased acute phase proteins may occur. ${ }^{11,13}$ A slight increase of $\operatorname{IgM}$, IgD and IgA can be noticed. PFAPA usually appears before the age of five as the most common cause of periodic fever in childhood. ${ }^{29}$ However, it is not an exclusive disease of childhood. The episodes recur every four to six weeks with complete resolution of symptoms between attacks. ${ }^{3,11,32,66}$

Pharyngitis is the most common symptom associated with fever and presents itself like an erythematous or exudative form, self-limited and with negative cultures. The aphthous stomatitis is characterized by small lesions, not keratinized, mainly located in the labial gingiva, is self-limited and appears a few days prior to the fever. ${ }^{11,13}$ Occur in $40-70 \%$ of PFAPA patients. ${ }^{18}$ These lesions may have bipolar distribution with oral and genital involvement. Less commonly, it may present as erythema predominantly on the trunk and palmoplantar macules or purpura. ${ }^{12}$ The disease usually has a benign evolution and resolves spontaneously in a high proportion of patients. ${ }^{11,29}$

The diagnosis is clinical and involves at least one of the three symptoms: aphthous stomatitis, pharyngitis and cervical lymphadenopathy. ${ }^{3,711}$ The diagnostic exclusion criteria include the presence of upper respiratory tract infection, cyclic neutropenia, primary immunodeficiency and hereditary autoinflammatory disease. ${ }^{7 \mathrm{~s}} \square$

\section{REFERENCES}

1. Kallinich T, Gattorno M, Grattan CE, de Koning HD, Traidl-Hoffmann C, Feist E, et al. Unexplained recurrent fever: when is autoinflammation the explanation? Allergy. 2013;68:285-96.

2. Neven B, Prieur AM, Quartier dit Maire P. Cryopyrinopathies: update on pathogenesis and treatment. Nat Clin Pract Rheumatol. 2008;4:481-9.

3. Ozen S, Frenkel J, Ruperto N, Gattorno M; Eurofever Project. The Eurofever Project: towards better care for autoinflammatory diseases. Eur J Pediatr. 2011;170:44552.

4. Martinon F, Mayor A, Tschopp J. The inflammasomes: guardians of the body. Annu Rev Immunol. 2009;27:229-65.

5. Rigante D, Cantarini L. Monogenic autoinflammatory syndromes at a dermatological level. Arch Dermatol Res. 2011;303:375-80.

6. McGonagle D, Aziz A, Dickie LJ, McDermott MF. An integrated classification of pediatric inflammatory diseases, based on the concepts of autoinflammation and the immunological disease continuum. Pediatr Res. 2009;65:38R-45R.

7. Rigante $D$. The fresco of autoinflammatory diseases from the pediatric perspective. Autoimmun Rev. 2012;11:348-56.

8. Shinkai K, McCalmont TH, Leslie KS. Cryopyrin-associated periodic syndromes and autoinflammation. Clin Exp Dermatol. 2008;33:1-9.

9. Yu JR, Leslie KS. Cryopyrin-associated periodic syndrome: an update on diagnosis and treatment response. Curr Allergy Asthma Rep. 2011;11:12-20.

10. Contassot E, Beer HD, French LE. Interleukin-1, inflammasomes, autoinflammation and the skin. Swiss Med Wkly. 2012;142:w13590.

11. Federici S, Caorsi R, Gattorno M. The autoinflammatory diseases. Swiss Med Wkly. 2012;142:w13602.

12. Braun-Falco M, Ruzicka T. Skin manifestations in autoinflammatory syndromes. J Dtsch Dermatol Ges. 2011;9:232-46.

13. De Sanctis S, Nozzi M, Del Torto M, Scardapane A, Gaspari S, de Michele G, et al. Autoinflammatory syndromes: diagnosis and management. Ital J Pediatr. 2010;36:57.

14. Krause K, Grattan CE, Bindslev-Jensen C, Gattorno M, Kallinich T, de Koning HD, et al. How not to miss autoinflammatory diseases masquerading as urticaria. Allergy. 2012;67:1465-74.

15. Dinarello CA. A clinical perspective of IL-1 $\beta$ as the gatekeeper of inflammation. Eur J Immunol. 2011;41:1203-17.

16. Kolivras A, Theunis A, Ferster A, Lipsker D, Sass U, Dussart A, et al. Cryopyrinassociated periodic syndrome: an autoinflammatory disease manifested as neutrophilic urticarial dermatosis with additional perieccrine involvement. J Cutan Pathol. 2011;38:202-8.

17. Goldbach-Mansky R, Kastner DL. Autoinflammation: the prominent role of IL-1 in monogenic autoinflammatory diseases and implications for common illnesses. J Allergy Clin Immunol. 2009;124:1141-9.

18. Dávila-Seijo P, Hernández-Martín A, Torrelo A. Autoinflammatory syndromes for the dermatologist. Clin Dermatol. 2014;32:488-501.

19. Giat E, Lidar M. Cryopyrin-associated periodic syndrome. Isr Med Assoc J. 2014;16:659-61.
20. Waynberger M, Dorra M, Tibi P, Slama R, Bouvrain Y. Valvular prostheses during the acute stage of bacterial endocarditis. Sem Hop. 1971;47:95-100.

21. Hoffman HM, Wanderer AA, Broide DH. Familial cold autoinflammatory syndrome: phenotype and genotype of an autosomal dominant periodic fever. J Allergy Clin Immunol. 2001;108:615-20.

22. Pereira AF, Pereira LB, Vale EC, Tanure LA. Four cases of Muckle-Wells syndrome within the same family. An Bras Dermatol. 2010;85:907-11.

23. Mathur AN, Mathes EF. Urticaria mimickers in children. Dermatol Ther 2013;26:467-75.

24. Hashkes PJ, Toker 0. Autoinflammatory syndromes. Pediatr Clin North Am. 2012 59:447-70.

25. Grateau G, Duruöz MT. Autoinflammatory conditions: when to suspect? How to treat? Best Pract Res Clin Rheumatol. 2010;24:401-11.

26. Tinazzi E, Puccetti A, Patuzzo G, Sorleto M, Barbieri A, Lunardi C. Schnitzler syndrome, an autoimmune-autoinflammatory syndrome: report of two new cases and review of the literature. Autoimmun Rev. 2011;10:404-9.

27. Fonnesu C, Cerquaglia C, Giovinale M, Curigliano V, Verrecchia E, de Socio G, et al. Familial Mediterranean Fever: a review for clinical management. Joint Bone Spine. 2009;76:227-33.

28. Aróstegui Jl. Hereditary systemic autoinflammatory diseases. Reumatol Clin. 2011;7:45-50.

29. Doria A, Dayer JM, Punzi L. Autoinflammatory diseases: how to put the fire inside the body out? Autoimmun Rev. 2012;12:1-4.

30. Almeida de Jesus A, Goldbach-Mansky R. Monogenic autoinflammatory diseases: concept and clinical manifestations. Clin Immunol. 2013;147:155-74.

31. Bhat A, Naguwa SM, Gershwin ME. Genetics and new treatment modalities for familial Mediterranean fever. Ann N Y Acad Sci. 2007;1110:201-8.

32. Lachmann HJ. Clinical immunology review series: An approach to the patient with a periodic fever syndrome. Clin Exp Immunol. 2011;165:301-9.

33. Yao Q, Furst DE. Autoinflammatory diseases: an update of clinical and genetic aspects. Rheumatology (Oxford). 2008;47:946-51.

34. Gomes JM, Gomes SM, Conde M. Autoinflammatory syndromes. Acta Reumatol Port. 2010;35:146-54.

35. Cantarini L, Lucherini OM, Muscari I, Frediani B, Galeazzi M, Brizi MG, et al Tumour necrosis factor receptor-associated periodic syndrome (TRAPS): state of the art and future perspectives. Autoimmun Rev. 2012;12:38-43.

36. Yao Q, Englund KA, Hayden SP, Tomecki KJ. Tumor necrosis factor receptor associated periodic fever syndrome with photographic evidence of various skin disease and unusual phenotypes: case report and literature review. Semin Arthritis Rheum. 2012;41:611-7.

37. Kanazawa N, Furukawa F. Autoinflammatory syndromes with a dermatological perspective. J Dermatol. 2007;34:601-18.

38. Bader-Meunier B, Florkin B, Sibilia J, Acquaviva C, Hachulla E, Grateau G, et al. Mevalonate kinase deficiency: a survey of 50 patients. Pediatrics. 201;128:e152-9. 
39. Mandey SH, Schneiders MS, Koster J, Waterham HR. Mutational spectrum and genotype-phenotype correlations in mevalonate kinase deficiency. Hum Mutat. 2006;27:796-802.

40. Cuisset L, Drenth JP, Simon A, Vincent MF, van der Velde Visser S, van der Meer JW, et al. Molecular analysis of MVK mutations and enzymatic activity in hyper-lgD and periodic fever syndrome. Eur J Hum Genet. 2001;9:260-6.

41. Bodar EJ, Drenth JP, van der Meer JW, Simon A. Dysregulation of innate immunity: hereditary periodic fever syndromes. Br J Haematol. 2009;144:279-302.

42. Simon A, van der Meer JW. Pathogenesis of familial periodic fever syndromes or hereditary autoinflammatory syndromes. Am J Physiol Regul Integr Comp Physiol. 2007;292:R86-98.

43. Touitou I, Koné-Paut I. Autoinflammatory diseases. Best Pract Res Clin Rheumatol. 2008;22:811-29.

44. Nevyjel M, Pontillo A, Calligaris L, Tommasini A, D'Osualdo A, Waterham HR, et al. Diagnostics and therapeutic insights in a severe case of mevalonate kinase deficiency. Pediatrics. 2007;119:e523-7.

45. Stankovic K, Grateau G. Auto inflammatory syndromes: Diagnosis and treatment. Joint Bone Spine. 2007;74:544-50.

46. Ammouri W, Cuisset L, Rouaghe S, Rolland MO, Delpech M, Grateau G, et al. Diagnostic value of serum immunoglobulinaemia $D$ level in patients with a clinical suspicion of hyper IgD syndrome. Rheumatology (0xford). 2007;46:1597-600.

47. Hayem F. Is Still's disease an autoinflammatory syndrome? Joint Bone Spine. 2009;76:7-9.

48. Cush JJ. Autoinflammatory syndromes. Dermatol Clin. 2013;31:471-80.

49. Shoham NG, Centola M, Mansfield E, Hull KM, Wood G, Wise CA, et al. Pyrin binds the PSTPIP1/CD2BP1 protein, defining familial Mediterranean fever and PAPA syndrome as disorders in the same pathway. Proc Natl Acad Sci U S A. 2003;100:13501-6.

50. Braun-Falco M, Kovnerystyy 0, Lohse P, Ruzicka T. Pyoderma gangrenosum, acne, and suppurative hidradenitis (PASH)--a new autoinflammatory syndrome distinct from PAPA syndrome. J Am Acad Dermatol. 2012;66:409-15.

51. Henderson C, Goldbach-Mansky R. Monogenic autoinflammatory diseases: new insights into clinical aspects and pathogenesis. Curr Opin Rheumatol. 2010;22:567-78

52. Demidowich AP, Freeman AF, Kuhns DB, Aksentijevich I, Gallin JI, Turner ML, et al. Brief report: genotype, phenotype, and clinical course in five patients with PAPA syndrome (pyogenic sterile arthritis, pyoderma gangrenosum, and acne). Arthritis Rheum. 2012:64:2022-7.

53. Tlougan BE, Podjasek JO, O'Haver J, Cordova KB, Nguyen XH, Tee R, et al. Chronic recurrent multifocal osteomyelitis (CRMO) and synovitis, acne, pustulosis, hyperostosis, and osteitis (SAPHO) syndrome with associated neutrophilic dermatoses: a report of seven cases and review of the literature. Pediatr Dermatol. 2009;26:497-505

54. Carneiro S, Sampaio-Barros PD. SAPHO syndrome. Rheum Dis Clin North Am. 2013;39:401-18

55. Walsh P, Manners PJ, Vercoe J, Burgner D, Murray KJ. Chronic recurrent multifocal osteomyelitis in children: nine years' experience at a statewide tertiary paediatric rheumatology referral centre. Rheumatology (Oxford). 2015;54:1688-91.

56. Al-Mosawi ZS, Al-Saad KK, ljadi-Maghsoodi R, El-Shanti HI, Ferguson PJ. A splice site mutation confirms the role of LPIN2 in Majeed syndrome. Arthritis Rheum. 2007;56:960-4.

57. Cassel SL, Janczy JR, Bing X, Wilson SP, Olivier AK, Otero JE, et al. Inflammasomeindependent IL-1 $\beta$ mediates autoinflammatory disease in Pstpip2-deficient mice. Proc Natl Acad Sci U S A. 2014;111:1072-7.

58. Hurtado-Nedelec M, Chollet-Martin S, Nicaise-Roland P, Grootenboer-Mignot S, Ruimy R, Meyer 0,et al. Characterization of the immune response in the synovitis, acne, pustulosis, hyperostosis, osteitis (SAPHO) syndrome. Rheumatology (Oxford). 2008;47:1160-7.

59. Majeed HA, Al-Tarawna M, El-Shanti H, Kamel B, Al-Khalaileh F. The syndrome of chronic recurrent multifocal osteomyelitis and congenital dyserythropoietic anaemia. Report of a new family and a review. Eur J Pediatr. 2001;160:705-10.

60. Bonamigo RR, Razera F, Olm GS. Neutrophilic dermatoses: part I. An Bras Dermatol. 2011;86:11-25.

61. Sfriso P, Caso F, Tognon S, Galozzi P, Gava A, Punzi L. Blau syndrome, clinical and genetic aspects. Autoimmun Rev. 2012;12:44-51.

62. Stoevesandt J, Morbach H, Martin TM, Zierhut M, Girschick H, Hamm H. Sporadic Blau syndrome with onset of widespread granulomatous dermatitis in the newborn period. Pediatr Dermatol. 2010;27:69-73.
63. Rosé CD, Aróstegui JI, Martin TM, Espada G, Scalzi L, Yagüe J, et al. NOD2associated pediatric granulomatous arthritis, an expanding phenotype: study of an international registry and a national cohort in Spain. Arthritis Rheum. 2009;60:1797-803.

64. Yazici H, Ugurlu S, Seyahi E. Behçet syndrome: is it one condition? Clin Rev Allergy Immunol. 2012;43:275-80.

65. van Daele PL, Kappen JH, van Hagen PM, van Laar JA. Managing Behçet's disease: An update on current and emerging treatment options. Ther Clin Risk Manag. 2009;5:385-90

66. Berkun Y, Levy R, Hurwitz A, Meir-Harel M, Lidar M, Livneh A, et al. The familial Mediterranean fever gene as a modifier of periodic fever, aphthous stomatitis, pharyngitis, and adenopathy syndrome. Semin Arthritis Rheum. 2011;40:467-72. \begin{tabular}{l}
\hline MAILING ADDRESS: \\
Alvaro Moreira \\
University Hospital of Erlangen \\
Department of Dermatology \\
Ulmenweg 18 \\
91054 Erlangen \\
Germany \\
Email: alvaro.moreira@uk-erlangen.de
\end{tabular}

How to cite this article: Moreira A, Torres B, Peruzzo J, Mota A, Eyerich K, Ring J. Skin symptoms as diagnostic clue for autoinflammatory diseases. An Bras Dermatol. 2017;92(1):72-80. 